\title{
An Evaluation of Takaful Insurance: Case of Pakistan
}

\begin{abstract}
Islamic finance being a relatively new business segment, however, have shown promising results so far. In addition to banking services, Islamic finance has started penetrating in other sectors including capital markets and insurance. This study aims to evaluate the newly emerging Takaful sector in Pakistani market. The study covers an overview of insurance sector including Takaful; comparative financial analysis of Takaful industry with conventional insurance; an insight into the accounting and legal framework for Takaful; a customer survey to document the perception about Takaful business; and an insight and documentation of challenges to Takaful operations. Findings suggest Takaful business has low market share, although growing at a faster pace. The past financial performance appears to be poor, though with singnificant potential depicted by healthy growth. A reasonably good regulatory framework is also in place. Overall, market sentiments are very positive about Takaful insurance in Pakistan.
\end{abstract}

Key Words: Takaful, Pakistan, market perception, regulatory framework, financial analysis

\section{Introduction}

During the twentieth century, liberation (or creation) of Muslim countries from colonial powers led these societies to evaluate the prevailing socio-economic systems critically through Islamic lenses. A mass movement of Islamisation of these societies started across the Muslim world [e.g. the Brotherhood and the Jamaat-e Islami movements] ${ }^{i}$. As part of the economic reforms, it was natural for them to consider, seriously, eliminating Riba (interest \& usury) from the economy. The conference of Organization of Islamic 
Cooperation (OIC) ministers (1973) in Jeddah was a significant milestone in this regard where the decision to establish an Islamic Development Bank (IDB) was made ${ }^{\mathrm{ii}}$. Similarly, other Muslim countries also took serious steps that paved the way for modern Islamic financial industry. Some of the important developments (reports/events/initiatives) in this respect are as follows: Report of the Council of Islamic Ideology-Pakistan (CII-1980) on elimination of interest; Tabung Haji program of Malaysia (1963) iiii Egypt's Mitghamer Bank (1963); Iranian revolution (1979); economy wide interest-free banking experiences in Pakistan ${ }^{\mathrm{iv}}$ and Sudan; research contributions of International Islamic University Islamabad ${ }^{\mathrm{v}}$ and Institute of Policy Studies ${ }^{\mathrm{vi}}$; Federal Shari'a Court ${ }^{\mathrm{vii}}$ and Supreme Court ${ }^{\mathrm{viii}}$ decisions $(1991,1999)$ against Riba in Pakistan; Raja Zafar-ul-Haq commission report and contributions by Justice (retd.) Taqi Usmani, Pakistan; establishment of Islamic banks in Malaysia, UAE, Bahrain, Qatar, Iran, KSA, Sudan and Pakistan; and the establishment of Accounting \& Auditing Organization for Islamic Financial Institutions (AAOIFI-1991) ${ }^{\text {ix }}$ and Islamic Fiqh Academy (IFA) Jeddah $1981^{\mathrm{x}}$. As part of the extension of Islamic banking project, Islamic finance rules were developed for capital markets and insurance (AAOIFI-2010, Shari'a Standard \# 12, 17, 21, and 26).

The global volume of Shari'a compliant assets has grown at about $16 \%$ per annum in post-financial crisis era (2007-08) with a volume of about US\$1,984 billion and is estimated to cross USD Five trillion by 2020 (GIFR-2015). The Middle East and North Africa (MENA) region is the center of Islamic finance market and contributes $73 \%$ share in global assets under Islamic finance, followed by Asia with $22 \%$, and the rest from all over the world (IFSB-2016). The share of bank assets is $79 \%$ followed by capital market operations with 19\% (Sukuk 15\% and equity funds 4\% approx.), and Takaful 1.2\%. By the end of 2015, the global volume of Takaful contribution is US\$23.2 billion (IFSB2016). 
Pakistan has been the champion in advocating Islamic finance since its inception, being the only state created in the name of Islam, among OIC countries. Constitution of Pakistan requires that the government in power should eliminate interest (Riba) from the economy (NAP-2010; articles 2, 31, 37, and 227). It was during the eighties when the then Government of Pakistan initiated a program to establish an interest-free economy. However, this program failed badly, primarily due to the shortage of well-trained human resources. From the early 2000s onward, Pakistan changed its policy towards the promotion of Islamic finance and started a parallel financial system to that of the conventional finance industry. By Sep 2016, 22 Islamic banks consisting of Six fullfledged Islamic banks and 17 conventional banks with Islamic banking divisions (SBP2016), five Takaful companies (SBP-2015), and 80 Islamic mutual funds (MUFAP-2016) are operating in Pakistan. Islamic financial services companies are managing an asset volume $^{1}$ of about US\$25 (PKR 2,492) billion including 57 Sukuk issues with a volume of US\$6.3 billion out of which Sukuk of US\$1 billion matured by September 2013 (Zawia2014). In Pakistan, Takaful operations started very recently, and at present, only five Takaful companies operate, however, the growth during the period 2009-15 is encouraging. Assets of Takaful sector increased by $600 \%$ in seven years from PKR2.7 billion in 2008 to PKR16.3 billion in 2015 (SBP-2015).

This study is aimed to explore Takaful operations in comparison with conventional insurance sector in Pakistan such as their relative growth and expansion, financial performance, regulatory \& accounting developments, Takaful models, reinsurance arrangements, and market perceptions about Takaful business. To the best of the authors'

\footnotetext{
${ }^{1}$ Volume of assets under Islamic banks is PKR 1,788 billion by September 2016, and under Takaful PKR 16.3 billion by December 2015 (SBP), under mutual funds PKR 158 billion by Jun 2016 (MUFAP). There are 57 Sukuk issues (from 1996-2013) with a volume of US\$ 6349 million; out of which Sukuk of US\$ 1052 million matured, hence assets under Sukuk are US\$5300 million (PKR 530 billion) by September 2014 (Zawia-2014).
} 
knowledge, there is hardly any such study in the context of Pakistan, and it is appropriate at this point, to unfold the issues of Takaful industry in Pakistan. The rest of the study is in the following order. The context of Takaful is discussed in Section II. Study objectives and methodology are stated in Section III, followed by results \& analysis in Section IV. Section V offers conclusion.

\section{Takaful Framework}

'Insurance' is a business activity engaged in diversification (sharing) of risks of one person (or business) among all participants. Traditionally, insurance companies provide indemnity to an individual or business against different risks, for a premium. Businesses are subject to many risks such as fire, theft, accidents, etc. and insurance companies are sources of risk mitigation/sharing. The concept behind the organization and management of insurance business is that of cooperation. Practically, the concept of mutual cooperation (i.e. insurance) has been commercialized in the modern business framework. From Islamic finance perspective, sharing of risk among the participants is permitted; Ayub, (2007) documented "Under Dham ${ }^{-}$an Khatr al-Tariq, losses suffered by traders during journeys due to hazards on trade routes were indemnified from jointly created funds. Islam accepted this principle of reciprocal compensation and joint responsibility. This principle is the foundation of the institution of "Takaful" - an alternative to conventional insurance in Islamic finance."

However, it can be argued that the practices of conventional insurance sector do not match with the spirit of cooperation, as encouraged in Islam. Following are the prime reasons/differences, which justify the creation and management of Takaful [AAOIFI2007 Shari'a Standard \# 26] independently from conventional insurance.

1. The conventional insurance contract is a financial mu'awadha (exchange contract) that aims at making a profit out of the insurance operations. Insurance company buys the risk 
of a customer for a premium leading to Gharar. ${ }^{2}$ Shari'a prohibits a transaction of Gharar in any business. ${ }^{3}$ Under the Takaful framework, the insurance company assumes the role of an agent to the participants to manage the insurance fund contributed by members and compensation is paid out of insurance fund.

2. Under the Takaful framework, any return on investment of insurance fund belongs to policyholders after deducting Mudarib's share [or Wakala fee] for an insurance company, while under conventional insurance, all returns belong to the insurance company against the commitment of making good the loss of policyholders. Under conventional insurance, revenues of an insurance company comes from premiums as well as total return on investments, while under Takaful, the insurance company earns profit as (a) an investor on its funds; (b) an agent to insurance fund, fee is earned; and (c) a Mudarib for managing investment of insurance funds.

3. Conventional insurance framework is a creation of local business laws, and no religious supervision is required while under Takaful Framework, an insurance company is bound to adhere to the rulings of Shari'a supervisory board in addition to local business laws.

4. At the time of liquidation, the surplus in insurance fund is required to be spent for charitable purposes under Takaful framework, while under conventional framework surplus belongs to shareholders of the insurance company.

Like conventional insurance, Takaful companies offer two types of policies, which are, asset insurance and life insurance (Takaful). Different steps involved in asset insurance process under Islamic financial system are as follows:

\footnotetext{
${ }^{2}$ According to SS \# 26, Gharar is what one cannot predict its unrevealed/unknown consequences. Something that may or may not occur/materialize.

${ }^{3}$ According to a Hadith, reported by Abu Huraira (RA), "The Prophet (PBUH) prohibited sales which involve Gharar" [Muslim, Abu Dawood, Tirmizi, Al Mowata, Ahmad, as reported in Shari'a standard].
} 
I. A customer enters into an insurance agreement by making payment of premium, which contributes to the insurance fund and signs the standard contract designed by the insurance company. The insurance company for services to be rendered for the management of insurance operations deducts a fee. Payments of any claims are made from the insurance fund

II. The insurance fund is invested by the insurance company in Shari'a compliant securities. The return on investment, as well as the original amount of investment, is refunded to the insurance fund at the completion of the period.

Under Takaful (life insurance), there are also two schemes in practice; first, in which a participant opts for protection only against disability and/or death, and the second; which is a combination of both investment and protection against disability and/or death. Steps involved in Takaful [life insurance without investment fund] insurance process are same as listed above. The second scheme of Takaful (life insurance) is a combination of investment and protection against disability and/or death. Following steps are involved in Takaful [with investment fund] insurance process under Islamic financial system:

I. The customer enters into in an insurance agreement by making payment of premium; a portion of the premium is a contribution to insurance fund and the remainder is an investment fund. Two contracts are signed by customer and insurance company: first is for appointing insurance company as an agent/trustee to manage the operations of the insurance fund and the second is for either appointing insurance company as an agent [Wakala Model] to manage investments or Mudarib/partner [Mudaraba Model]. A fee is charged by the insurance company for services to be rendered for the management of insurance operations. All claims are paid out of insurance fund. 
II. Amounts of the insurance fund, as well as, investment fund, are invested by the insurance company in Shari'a compliant securities. The return on investment, as well as the original amount of investment, is refunded to insurance and investment funds.

III. Upon termination/maturity of an insurance policy, funds are paid from investment balance in the account of a customer by the terms of the agreement.

As for reward of an insurance company is concerned, there are the two suggested models of insurance under Islamic finance, commonly known as Wakala model and Mudaraba model.

1. Wakala model suggests that being a trustee of insurance funds as well as manager of investments, compensation to the insurance company should be given as a fixed predetermined fee for its services. Hence, under this model, the insurance company receives two types of fees: a fee for management of insurance fund, and another for managing the investment operations of insurance and investment funds of policyholders (if any).

2. While under Mudaraba model, the reward of an insurance company is a combination of fee for managing insurance operations and a share in actual profit from return on investments made from insurance and investment funds.

There can be a situation under Takaful framework when a claim is filed, but insurance fund is unable to pay it fully. In this case, following options are available to a Takaful company to manage the shortfall:

a. Make payment to policyholder equal to the amount available in insurance fund; however, this will affect the business of Takaful negatively, especially given the competition from the conventional insurance industry, or

b. Make partial payment in cash and promise to pay the balance once further premiums are deposited in the insurance fund; or 
c. Make full payment of a claim by obtaining interest-free loans (Qard-e-Hasan), if available ${ }^{4}$.

Although in principle, it is agreed as well as preferred to have a council of participants to monitor the operations of Takaful given the cooperative nature of activity. However, in practice, it is managed by a joint stock company having professional skills and expertise for a fixed sum of fee out of the contributions. Hence, the role of an insurance company is vital in managing the affairs of a Takaful system. It is the insurance company that is responsible for all types of documentations, management of insurance operations, and investments. In practice, an insurance company is registered with a local regulator (e.g. Securities and Exchange Commission in Pakistan - SECP) ${ }^{5}$.

There is not much literature in the area of Takaful insurance as far performance evaluation is concerned given the nascent stage of the industry, however, few important studies are being reviewed as under. Coolen- Maturi, (2013) conducted a study in UK Market and documented two important findings including lack of awareness about Takaful among UK Muslims communities, and willingness to buy Takaful services if prices and coverage are competitive with conventional insurance sector. Akhter \& Hussain, (2012), documented lack of awareness about Takaful among insurance customers, based on a survey in a Muslim majority country, Pakistan. Hidayat and Abdulla (2015) conducted a detailed financial analysis of Takaful and conventional insurance sector in Bahrain and documented important findings relating to profitability, efficiency, and liquidity. As per results, conventional insurance companies performed

${ }^{4}$ Option $\mathrm{C}$ is being practiced by Takaful companies by providing interest free loans from the wealth of the shareholders in order to keep running the insurance operations. Successful running of insurance business is in the interest of an insurance company making it a win-win situation.

${ }^{5} \mathrm{~A}$ set of rules relating to insurance policies is written in articles of association. After registration a standard agreement is prepared by insurance company and got signed from participants. This standard agreement contains terms and conditions of insurance policy including amount of premium as well as compensation. 
better than Takaful companies in terms of profitability and efficiency while Takaful sector turned out better in liquidity management during the study period (2006-2011). Yusuf \& Babalola (2015) conducted a premier study on Takaful sector in Nigeria and documented the lack of awareness among masses and a skillful workforce trained in Islamic finance, a common phenomenon globally in the area of Islamic finance. To the best of our knowledge, there is no study on a comprehensive evaluation of Takaful insurance in the domestic market, and this is the right time to study Takaful sector of Pakistan and document findings, challenges and recommendations.

\section{Study Objectives \& Methodology}

Insurance is all about sharing risks by participants. Accordingly, insurance is one of the risk management/mitigation tools. Modern insurance has been transformed into an important business segment. This study aims to gain an insight into Takaful operations in comparison with conventional insurance sector in Pakistan. More specifically, it analyzes their growth and expansion, financial performance, regulatory and accounting developments, Takaful models, reinsurance arrangements, and market perception about Takaful business. In summary, this study has following objectives:

1. An overview of insurance industry in Pakistan;

2. Comparative financial performance evaluation;

3. Legal and financial reporting issues in Takaful;

4. Market [prospective customers] survey.

The study period is $2008-15$. For this study, financial data is extracted from Financial Statement Analysis of Financial Sector available from State Bank of Pakistan [SBP hereafter]; regulatory framework from Securities \& Exchange Commission of Pakistan [SECP, 2005 \& 2012]; accounting issues from Accounting \& Auditing Organisation of Islamic Financial Institutions [AAOIFI, 2008] and International Accounting Standard 
Board [ASB, 2011]; market perception survey of finance professionals conducted in domestic market; and operations information from Takaful workforce of local companies. The analysis is conducted using different relevant financial ratios and statistical techniques. For an overview of the insurance industry, various reports of SECP including Insurance companies' guidebook (2012), annual report (2012), economic survey (2013), and balance sheet analysis of financial sector (SBP, 2015) were consulted. Performance evaluation is done by calculating growth in assets, profitability, return on equity, net claim to net premium ratio, underwriting results, and returns on investments earned during the period under review. Risk outsourcing is measured through net premium to gross premium and net claims to gross claims ratios. Results of insurance sector are used as the benchmark. To get an insight into the accounting \& regulatory issues, AAOIFI and SECP regulations including Shari'a standards, accounting standards, insurance companies' ordinance (2000), companies' ordinance (1984), Takaful rules (2005) and Takaful rules (2012) alongwith annual reports of companies are consulted. To understand the perception of the market (prospective customers), a survey with a focus on local accounting bodies' (ICMAP/ICAP) ${ }^{6}$ members and business graduates with industry/academic experience ${ }^{7}$ was conducted by using SurveyMonkey services in the month of January 2014. The accounting/finance professionals were selected based on their familiarity with and understanding of financial matters and their role in financial decision making as accounting/finance professionals. Results are presented through descriptive statistics and graphs.

\section{Results and Analysis}

\section{a. Insurance Sector}

${ }^{6}$ ICMAP is Institute of Cost and Management Accountants of Pakistan and ICAP is Institute of Chartered Accountants of Pakistan.

${ }^{7}$ Only $9 \%$ of respondents having experience less than five years. 
In Pakistan, there were 51 insurance companies [7 life insurance, 39 general insurance, and 5 Takaful], with an asset volume of PKR876 billion (US\$9 billion approximately), by the end of December 2015 (SBP, 2016). Assets of insurance sector have shown a stable growth, with a median of 15\%, over 2009-15 period. In 2012 alone, the assets increase by $19 \%$. A premium amounting to PKR234 billion (USD2.34 Billion) was collected and claims amounting to PKR 89 billion (USD 890 Million) were registered and approved during 2015. Premiums, as well as claims, have shown a steady growth (median) of 16\% and 9\% respectively during the study period (2009-15). This sector has also contributed to national exchequer an amount of PKR 5 billion as income tax during the year of 2015. Return on equity remained 19\% in 2015 while five-year median ROE was $15 \%$. The size of insurance sector is about $3 \%$ of GDP (9/271), showing a huge potential yet to be capitalized ${ }^{8}$. Insurance companies are regulated by insurance companies' ordinance 2000. There were 5 Takaful companies working in Pakistan with an asset volume of PKR16 billion by the end of December 2015. During this year, the premium collected amounted to PKR9 billion and claims registered/approved amounted to PKR3 billion. Takaful business is regulated through companies' ordinance 1984, insurance ordinance 2000, Takaful companies' rules $2005 \& 2012$. The size of Takaful stream was just about 2\% of the insurance sector in Pakistan as at December 2012.

\section{b. Financial Analysis}

This section presents the comparative financial analysis regarding growth, risk management, and profitability over the seven-year period (2009-15) of Takaful and overall insurance sector. Trends are presented in graphic form in the appendix. Figure 1 presents the growth of assets under Takaful in Pakistan during the study period showing an increasing trend. It shows that the assets of Takaful doubled in three years [2009-11]

\footnotetext{
${ }^{8} \mathrm{http}: / /$ www.tradingeconomics.com/pakistan/gdp.
} 
and were six times more in 2015 than those in 2008. It is important to note that during this era, conventional industry assets increased to three times only and the GDP growth rate in the country remained below $5 \%$. This trend shows a significant increase in assets under Takaful than the conventional insurance, a clear evidence of market interest and potential for growth in Takaful in Pakistan.

Figure 2 presents the growth rates (in annual percentages) in assets of Takaful and conventional insurance sectors, showing significant differences between the two from 2010 onwards. Although there is an overall increasing trend in the volume of assets under insurance sector, however, Takaful has grown at a faster rate than conventional insurance during the period under review. In spite of infancy of Takaful sector, growth in assets is very impressive and shows an increasing trend from just 9\% in 2009 to a marvelous figure of 50\% and $45 \%$ in 2012 and 2013, respectively.

Figure 3 provides the profitability trend, an indication of operating performance of Islamic insurance companies, showing losses from 2008 to 2011 and profit onwards except in 2015. This is typical for any industry in its infancy stage i.e. high growth but with losses during the first few years. However, in the medium to long run, it is important for the Takaful firms to be profitable, as no business can survive in the long-run without earning profits. During this period, conventional insurance sector remained profitable except in 2008.

Poor profitability resulted in a negative return on assets as well as negative Return On Equity (ROE) as shown in Figure 4. Although ROE is negative in initial years (2008-11), however, it recovered in 2012 and 2013 with an increasing trend but turned negative in 2015. Still, it is far behind than conventional insurance, and a potential threat to the Takaful sector as a viable business opportunity.

An important performance measure in the insurance business is the ratio of claims to premiums. In the case of conventional insurance, it is an important variable in the 
determination of profitability of a company, as a smaller ratio means more profits and vice versa. However, in the case of Takaful, it has little to do with the profitability of the company as claims and premiums are dealt through the insurance account, representing the ownership of trust (know as 'Waqf'). Still, it has implications for the success of Takaful model as claims are needed to be entertained, and lesser claims mean more stability and success. As per results reported in Figure 5, Takaful paid more claims than conventional insurance did, across all years. The difference in claims to premium ratio paid by Takaful in comparison to conventional insurance ranges from $32 \%$ in 2008 to $16 \%$ in 2011. These figures are based on NC/NP after deductions are made for reinsurance, clearly, leading to a conclusion that reinsurance arrangements of conventional insurance are better than those for Takaful.

Another important source of earnings for an insurer is the underwriting fee. Underwriting income is generated through selling new policies. Ideally, it should be depicted as a percentage of profit, however, in the case of Takaful, the underwriting figures are negative as shown in Figure 6. For, half of the period under review, underwriting income is positive. However, the amounts are rather smaller. Ideally, an insurance company should be in profit on underwriting business.

Another aspect of the insurance business is the share of risk outsourced by the insurance company which is depicted through net premium to gross premium ratio. Figure 7 presents the comparative risk bearing ratio for both streams of insurance. As per figures reported, Takaful companies outsource most of their risk as compared to the conventional insurance sector. Median risk bearing figure for conventional insurance is $79 \%$ while for Takaful companies; it is just $28 \%$. Hence, Takaful companies are less risky as compared to conventional insurance companies.

Outsourcing of risk is beneficial only if actual claim-service matches with the amount of premium passed onto the reinsurer. Figure 8 presents the comparative position of 
conventional versus Takaful companies based on net claims to gross claims ratio. Median contribution by reinsurer under the conventional system is $21 \%$ while under Takaful, it is $35 \%$. This shows the inefficiency of bargaining with reinsurer as well as selection of reinsurance contract. It was discussed above that a major portion of premium (72\%) is passed on to reinsurer while contribution in claims is $35 \%$ for Takaful companies while conventional companies pass only $21 \%$ of the premium and receive a contribution in claims equal to $21 \%$.

Another important source of earnings as well as measure of performance is returns on investments made by a company out of funds available for investment. This ratio can be calculated as a share in net profit or as a return on investment. Given the negative results in profitability of Takaful companies, we selected the latter approach and trends over the years are presented in Figure 9.

In the case of returns on investments made by insurance companies as well as Takaful companies, a median ROI is 4\%, although the average is different. From 2008-12, conventional sector outperformed Takaful in ROI, however, for last three years ROI is similar for both streams, though very low $(2 \%)$. On this front, Takaful sector faces challenges. For example, in the case of conventional companies, opportunities for investment are far more than those available to Takaful companies, given the condition to invest only in Shari'a compliant securities. Islamic capital market including the equity and Sukuk securities are gradually getting mature in Pakistan.

To conclude, there is a great potential for Takaful companies in Pakistan and efforts are being made to develop this sector. However, over the seven years period of 2009-15, their performance at best is mixed. Growth and expansion are very healthy, however, profitability is poor. There are certain challenges for Takaful companies in Pakistan including better negotiation with the reinsurer, development of profit-oriented underwriting models, and tapping the less risky business sectors. 


\section{c. Regulatory Framework}

The legal structure in Pakistan is common English law, similar to that of United Kingdom, as it used to be a British Colony. With the passage of time, since Pakistan's independence in 1947, changes have been made to accommodate new developments. Insurance sector in Pakistan is regulated by a number of different regulatory regimes such as The Companies Ordinance 1984 (SECP-2002); Companies (Issue of Capital) Rules 1996 (SECP-1996); The Insurance Ordinance 2000 (SECP-2011); The Insurance Rules 2002 (SECP-2002); The Takaful Rules 2005 (SECP-2005); The Insurance Companies (Sound and Prudent Management) Regulations 2012 (SECP-2012); and Takaful Rules 2012 (SECP-2012). To start a Takaful insurance business, a company has to register under Companies' Ordinance 1984. A foreign company with $100 \%$ ownership can operate by meeting the minimum capital requirement of US\$4 million, $50 \%$ of which must come from abroad. Minimum capital to conduct life insurance business is PKR500 million, and for general Takaful, it is PKR 300 million, irrespective whether the intended business falls under conventional or Takaful sectors, respectively. Upon incorporation, the company is required to get itself registered under the Insurance Ordinance (2000) with insurance division of SECP. To be a registered insurer, detailed criteria are listed in Section 6 of the Ordinance (2000), which ensures transparency, managerial skills, and justice among the stakeholders. In addition to fulfilling Section 6, an intended Takaful company needs to comply with Takaful Oompanies' Rules (of 2005 and 2012). These rules require from a Takaful company to comply with the following:
a. Separate company for life and general Takaful
b. Single company can work for both conventional and Takaful
c. Principal operational model is Wakala (for risk management) and Mudaraba (for investment); however, Wakala is also allowed for investment management.


Investments must be made according to the Islamic finance principles under the supervision of Shari'a board.

d. Participants' Takaful Fund (PTF) is required to be maintained for dealing in risk management including contributions, re-takaful revenues, return on PTF's investments and charged with direct expenses (except office expenses), re-takaful cost, payment of claims, Wakala fee and share of Mudarab (Takaful company) in investment returns and creation of reserves and surplus distributions. In the case of a deficit, Qard-e-Hassan (interest-free loan) financing is allowed (in fact, it is required that operator undertake to pay the losses through Qard-e- Hassan in the case of the deficit), with the right to recover from future earnings of PTF.

e. Surplus/deficit shall be calculated at least annually, and surplus shall be distributed to participants in cash or reduction of contributions or used for charity if consented so by a participant and/or a group.

f. If Shari'a compliant re-takaful is not available then with the approval of Shari'a board re-takaful can be obtained from conventional reinsurance companies.

g. Establishment of Shari'a board and Shari'a compliance audit is necessary. Except for a detailed criterion for liquidation and distribution of surplus in PTF, in the case of ceasing operations, a comprehensive accounting and regulatory framework are being laid down by SECP to regulate Takaful business in Pakistan. Legislation has also included a reference to AAOIFI accounting standards. Additionally, a reference to Shari'a compliant filters for investments is cited. Shari'a governance mechanism in addition to general corporate governance compliance is also required. However, a need for a full-fledged law on Takaful as well as the full adoption of AAOIFI standards cannot be ruled out.

\section{d. Market Survey}


To gain insight into the market perception of Takaful business, a survey of accounting/finance and business graduates with industry and academic experience was conducted in the month of January 2014. We considered business and finance graduates/professionals as the most relevant population with an understanding of risk mitigation through insurance. We contacted these professionals via email. We received 73 responses in total. Given the experience, expertise, and relevant education, this number is considered sufficient to form an opinion about the market perception. Survey demographics show that $74 \%$ of respondents are working as accounting/finance professionals with a membership of local accounting bodies (i.e. ICMAP, ICAP, etc.), followed by $16 \%$ with postgraduate education, $8 \%$ business graduates (MBA), and $4 \%$ PhDs. 96\% respondents are male, and only $4 \%$ are female. The median age of the respondents is 39 (average 41) with a median experience of 15 (average 16) years. Survey questions and results (graphs) are provided in the appendix.

The first question required the respondents to show if the conventional insurance is Halal (permissible) or Haram (prohibited). 73\% respondents perceive it Haram, 10\% as Halal, while $17 \%$ were not sure about it. Hence, an overwhelming majority subscribe to the view of Islamic Fiqh Academy and AAOIFI, which seems very helpful for the development of Takaful business in Pakistan.

In response to the second question of what is the underlying reason for conventional insurance business to be classified as Haram, $41 \%$ chose Gharar (high risk), and 68\% chose Riba (interest). It is pertinent to note that even after eliminating Riba; conventional insurance would be a Haram business as its makeup is based upon Gharar. Respondents clearly missed the underlying reason for conventional insurance to be Haram. This shows that there is a lack of education and understanding about the underlying reasons as to why the conventional insurance is Haram. 
As for insurance status is concerned, $25 \%$ of respondents do not use insurance services, however out of insured persons, $75 \%$ are using conventional insurance services while Takaful companies serve $25 \%$. It is clearly an indication of the great potential for Takaful business in Pakistan.

The fourth question was about the opinion of respondents as to how the Takaful is different from conventional insurance. $25 \%$ perceive there is no difference. However, an overwhelming majority of $66 \%$ is of the opinion that due to Gharar and/or Riba, Islamic and conventional insurance are different business system.

In response to the question, whether respondents are willing to adopt Takaful if offered at competitive rates, 59\% chose 'very likely' to adopt, $32 \%$ showed moderate likeness and slight likening while only $10 \%$ were not willing to adopt. These responses clearly favor the adoption of Takaful, if offered at competitive rates. Coolen-Maturi, (2013) has also documented willingness of Insurance customers in the UK to adopt Takaful services.

Another question was about the satisfaction of respondents about the regulatory framework for Takaful business in Pakistan. 52\% of respondents were dissatisfied with the prevailing regulatory framework and suggested a separate law (act/ordinance) for regulation of Takaful business. $30 \%$ perceives that Shari'a supervision is weak; $42 \%$ of respondents were of the opinion that SEC Takaful rules are satisfactory; and 25\% of respondents suggested the adoption of AAOIFI framework for regulation of Takaful in Pakistan.

The ninth question was about the capacity of the Takaful system to meet the needs of businesses and households. 59\% respondents showed their confidence in the ability of the system to serve the market while $33 \%$ remained skeptical about the capacity of Takaful business to serve the market.

In response to a question about the future of this new (Takaful) stream of insurance in Pakistan, a negligible minority of $4 \%$ show that its future is bleak, $37 \%$ believe it has a 
very promising future, $40 \%$ perceive it will continue at existing pace while $26 \%$ believe it will remain the second best choice following conventional insurance.

The final question was about an academic/professional qualification of Islamic finance offered (or to be offered) by universities. A clear majority of $62 \%$ suggests professional qualification (e.g. CA, CMA, and MBA) with specialization in Islamic finance [a blend of conventional and Islamic finance], followed by $49 \%$ favoring MS/Ph.D. in Islamic finance while $36 \%$ endorsed certification as well as a module on Islamic finance. This shows that market welcomes education/training/qualification in the area of Islamic finance in the shapes of professional qualification, Master/Ph.D., certification/diploma, as well as an introductory module on Islamic finance for business/finance graduates. Strengthening workforce in the area of Islamic finance is also documented by Yusuf \& Babalola (2015).

In sum, the results suggest that an awareness campaign is needed about the availability of Islamic finance products in general, as well as offering a professional qualification for upcoming business graduates. Additionally, a separate law based on AAOIFI framework to regulate Takaful business is needed, ensuring strong Shari'a supervision. Potential of Takaful remains positive in Pakistan, and this industry needs to tailor its services according to business and household needs.

\section{Conclusion}

This study was aimed at evaluating Takaful industry in Pakistan. It considered the operations, regulatory framework, financial performance, and market perception. Data was extracted from annual reports of Takaful companies operating in Pakistan, SEC regulations, and market survey of accounting/finance professionals. It concludes that despite the significant potential, Takaful has not been very successful in penetrating the insurance business. Financial performance of Takaful companies operating in Pakistan is 
poor as compared to conventional insurance companies except for growth and expansion. Although a reasonably good regulatory framework is in place, however, an independent law based on AAOIFI framework would provide additional confidence to the market. Despite very positive sentiments about Takaful business in Pakistan, there are certain challenges faced by Islamic finance industry as a whole. These are being discussed as under:

1. Perception of the market needs to be clarified urgently. Hanif (2012), documented, based on a survey of 100 finance professionals, that $44 \%$ of practitioners do not consider the practice of current Islamic banking industry in Pakistan as Shari'a compliant. Similarly, based on the current survey of finance professionals, we find that a reasonable proportion of participants do not consider current practices of conventional insurance as non-Shari'a compliant. Islamic finance industry in general and Takaful sector in particular, needs to educate the market through conferences, seminars and print and electronic media about the differences in conventional and Islamic financial industry.

2. Another important issue is the lack of innovative products offered to participants. In addition to the compliance with the legal form, the market would also like to see the economic substance of Islamic finance transactions.

3. Linking the profit rate with KIBOR by Islamic finance industry has created misconception among the customers. Charging profit based upon KIBOR in every sector does not match with the essence of Islamic finance. Market risks and returns of different sectors are more in line with the precepts of Shari'a; hence Islamic finance industry needs to look into the matter to draw a mechanism based upon actual strengths and weaknesses of a particular sector. 
4. Re-Takaful practices of the insurance industry are a source of risk mitigation, however, at present, there are limited Shari'a compliant opportunities in this respect. An issue needs to be addressed, globally, by a consortium of global Takaful market.

5. Analysis has shown that Takaful companies operating in Pakistan are at a consistent disadvantage as for re-Takaful gains, and underwriting profits are concerned. There is a need to develop efficient business models to address the issue.

6. Continuous losses in Takaful industry could lead to the closure of Takaful firms. This is a serious issue to be addressed by Takaful industry collectively. One of the reasons is the inefficient (financially) investments made by Takaful companies. Undoubtedly, avenues are limited for Takaful companies in comparison with conventional industry, however, out of the box thinking can turn around this trend.

7. Trained human resources in the area of Islamic finance is a global issue, and only educational/professional institutions can help in meeting it demand. Neither good finance education nor good Shari'a education alone can address the issue. There is a need to develop academic and professional programs like MBA/CMA/CA with specialization in Islamic finance to address this human resource problem.

\section{References}

AAOIFI (2008). Accounting, Auditing and Governance Standards, P.O.Box 1176, Manama, Bahrain. [Accounting and Auditing Organization for Islamic Financial Institutions]

AAOIFI (2010). Shari'a Standards, P.O.Box 1176, Manama, Bahrain. [Accounting and Auditing Organization for Islamic Financial Institutions]

Akhter, W., \& Hussain, T., (2012) "Takāful standards and customer perceptions affecting takäful practices in Pakistan: a survey," International Journal of Islamic and Middle Eastern Finance and Management, Vol. 5 Iss: 3, pp.229 - 240

Ayub, M., (2007). Understanding Islamic Finance. John Wiley \& Sons Ltd, The Atrium, Southern Gate, Chichester, West Sussex PO19 8SQ, England 
CII -1980. Report on Elimination of Riba from Economy, Council of Islamic Ideology, Islamabad, Pakistan.

Coolen- Maturi, T., (2013) "Islamic insurance (takaful): demand and supply in the UK," International Journal of Islamic and Middle Eastern Finance and Management, Vol. 6 Iss: 2, pp. 87 - 104

GIFR-2015. Global Islamic Finance Report. Available at www.edbizconsulting.com accessed on January 9, 2017

Hidayat, S.E., and Abdulla, A.M., (2015). A Comparative Analysis on the Financial Performance between Takaful and Conventional Insurance Companies in Bahrain during 2006-2011. Journal of Islamic Economics, Banking and Finance, Vol. 11 No. 2, Pages 149-63.

IASB-2011. International Financial Reporting Standards, 30 Cannon Street, London EC4M 6XH, United Kingdom.

IFSB-2016. Islamic Financial Services Board Stability Report 2016. http://www.ifsb.org/docs/IFSI\%20Stability\%20Report\%202016\%20(final).pdf accessed on March 7, 2017

MUFAP-2016. Annual Report 2016. Mutual Funds Association of Pakistan. http://www.mufap.com.pk/ accessed on January 1, 2017.

NAP-2010. Constitution of the Islamic Republic of Pakistan. National Assembly of Pakistan. http://www.na.gov.pk/uploads/documents/1308922472 189.pdf accessed on September 24, 2014.

SBP- 2015. Financial statements of financial sector. www.sbp.gov.pk accessed on Feb 4, 2017.

SBP- 2016. Islamic Banking Bulletin. www.sbp.gov.pk accessed on March 7, 2017.

SECP-2011. Insurance Ordinance 2000 [updated November 2011], available at http://www.secp.gov.pk/corporatelaws/pdf/InsuranceOrdAmended-Nov2011.pdf accessed on 13$\underline{01-2014}$.

SECP-2012. Insurance Guidebook: incorporation, registration, licensing; available at http://www.secp.gov.pk/Guides/InsuranceGuidebook-IncorporationRegistrationLicensing.pdf accessed on 13-01-2014.

SECP-1996. Companies (Issue of Capital) Rules-1996. http://www.secp.gov.pk/Capital-Issues-\&Public-Offerings/Equity Market/The-Companies(Issue-of-Capital)Rules-1996.pdf accessed on September 24, 2014. 
SECP-2002. Companies Ordinance 1984.

http://www.fmu.gov.pk/docs/laws/CompaniesOrdinance1984(amended).pdf accessed on September 24, 2014.

SECP-2002. Insurance Rules.

http://www.secp.gov.pk/corporatelaws/pdf/Insurance_Rules_2002\%20_NotifiedbyMinistryofCom merce.pdf accessed on September 24, 2014.

SECP-2005. Takaful Rules-2005.

http://www.secp.gov.pk/corporatelaws/pdf/Takaful_Rules_2005.pdf accessed on January 1, 2014.

SECP-2012. Insurance Companies (Sound \& Prudent Management) Regulations 2012. http://www.secp.gov.pk/notification/pdf/2012/InsuranceCompaniesSoundandPrudentManagement Regulations2012.pdf accessed on September 24, 2014.

SECP-2012. Takaful Rules-2012. http://www.secp.gov.pk/notification/pdf/2012/Takaful-Rules2012.pdf accessed on January 1, 2014.

Yusuf, T.O., \& Babalola, A.R., (2015) Takaful in Nigeria: Penetration Challenges and Way Forward. Journal of Islamic Economics, Banking and Finance, Vol. 11 No. 2, pages 133-48.

Zawia (2014). http://www.zawya.com/files/islamic-reports/tr-sukuk-perceptions-and-forecast2014.pdf accessed on January 15, 2014. 


\section{Appendix}

\section{1-Financial Analysis}

Figure 1. Growth in assets under Takaful for 2008-15, in Pakistan PKR Million

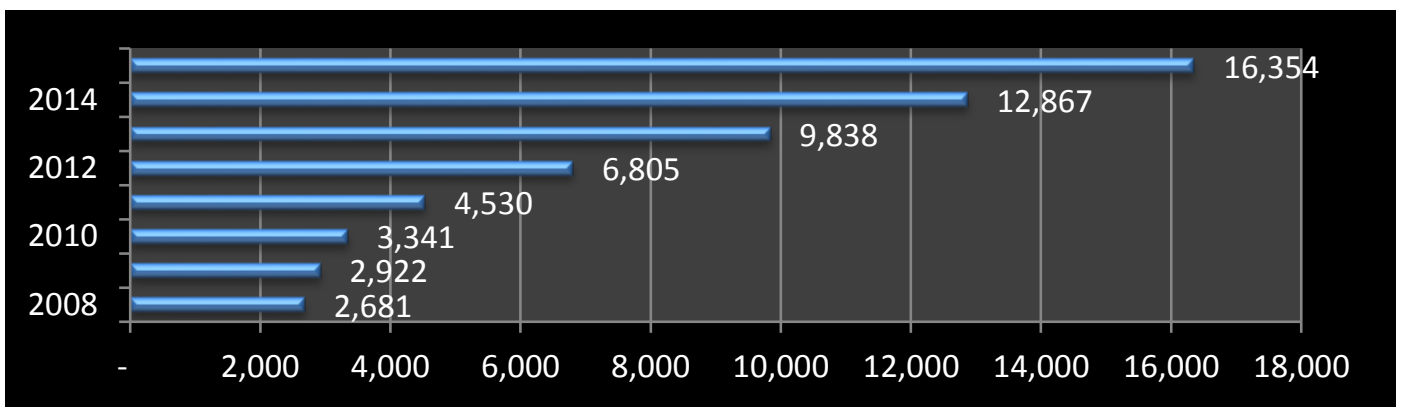

Data Source: SBP-2015

Figure 2. Comparative Growth rate in Assets under Insurance \& Takaful for 2009-15

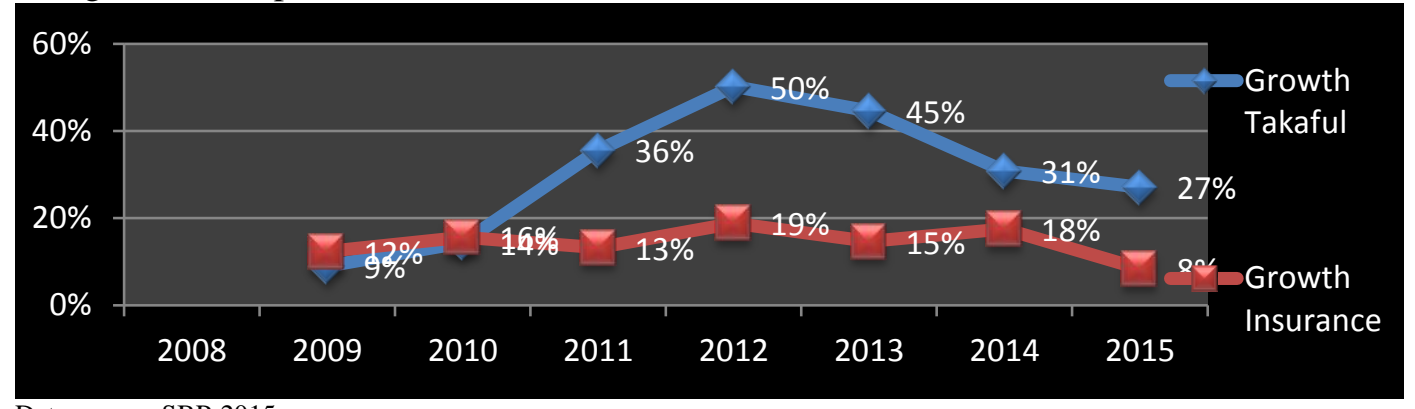

Data source: SBP-2015

Figure 3. Profitability of Takaful sector during 2008-15 PKR Million

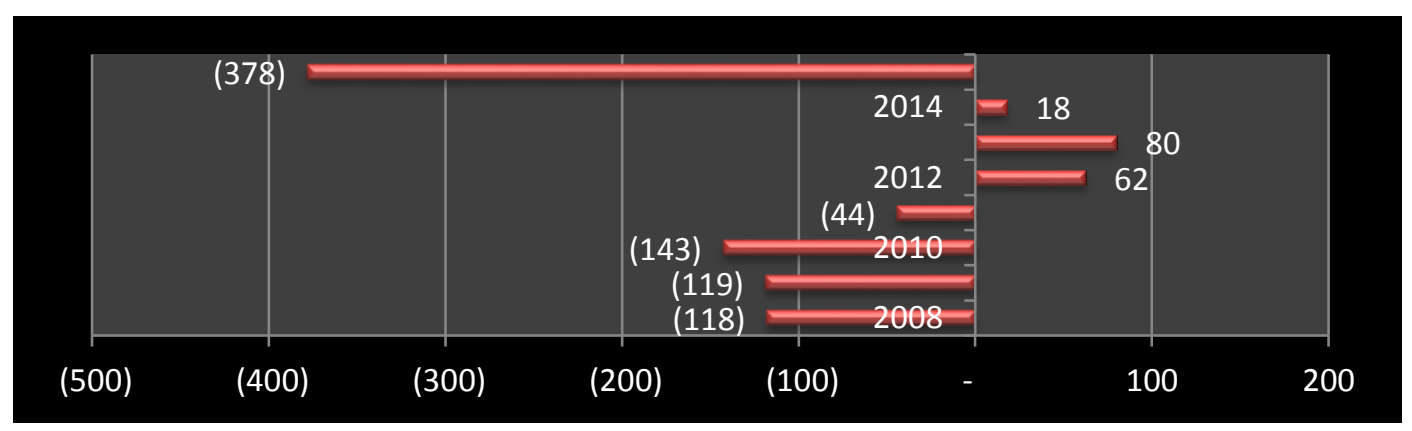

Data source: SBP-2015 
Figure 4. Comparative return on equity in Insurance and Takaful for 2008-15

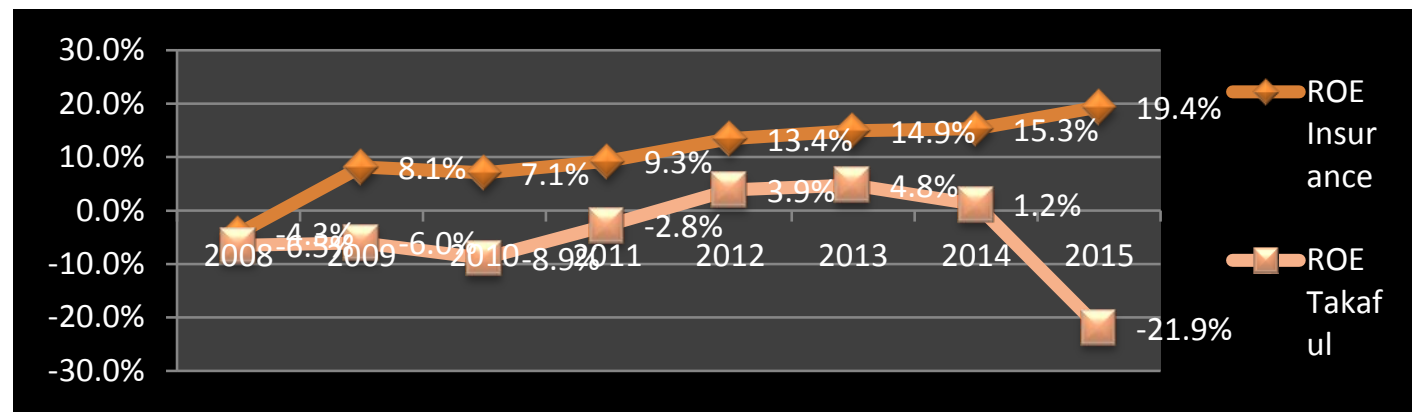

Data source: SBP-2015

Figure 5. Comparative NC/NP for insurance and Takaful in Pakistan for 2008-15

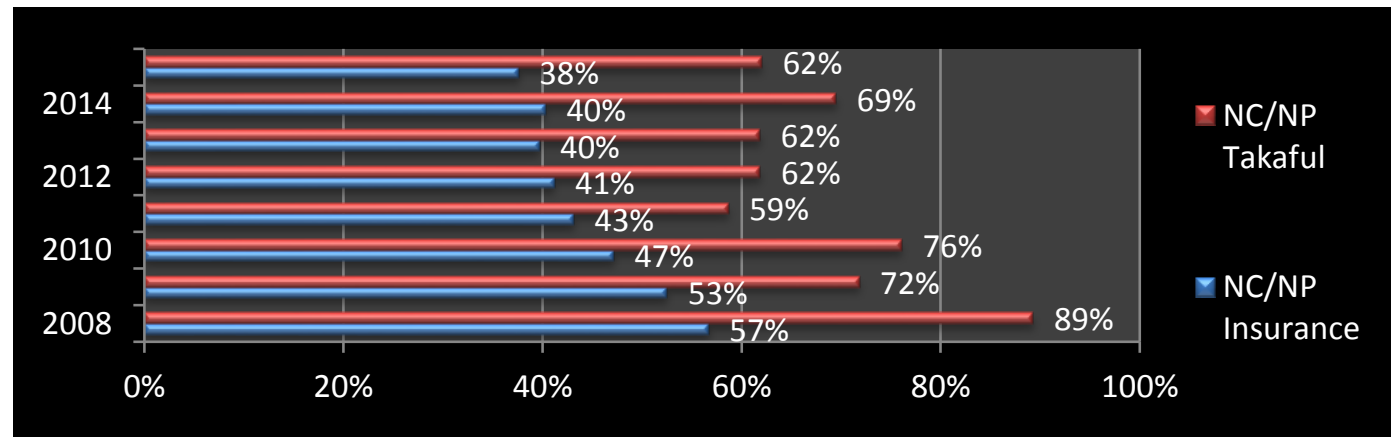

Data source: SBP-2015; NC=Net Claims; NP=Net Premium

Figure 6. Underwriting profit/loss generated during 2008-15 by Takaful companies PKR Million

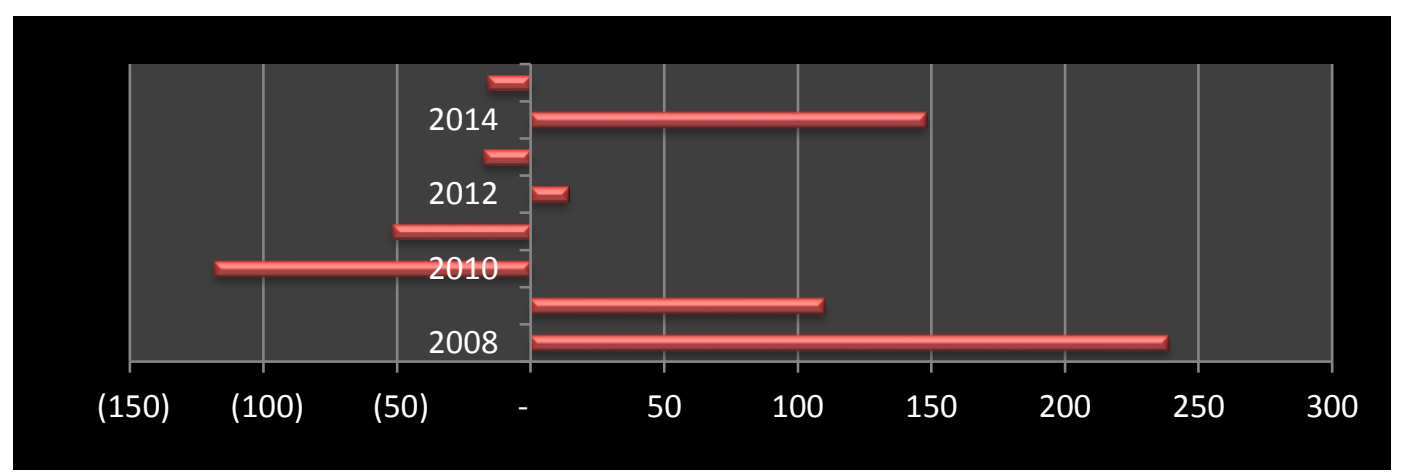

Data source: SBP-2015 
Figure 7. Net Premium (NP) to Gross Premium (GP) ratio of Takaful and Insurance, 2008-15

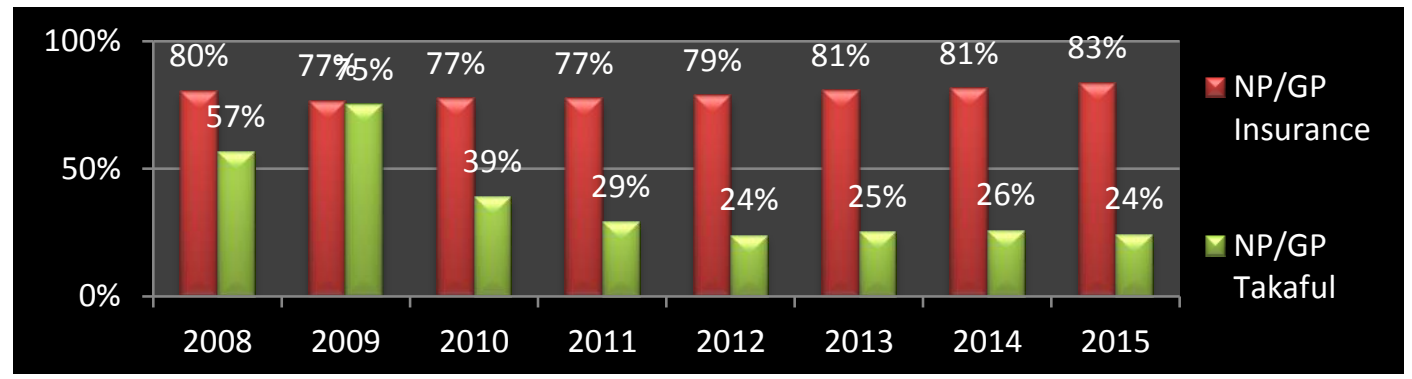

Data source: SBP-2015

Figure 8. Comparative ratios of Net Claims (NC) to Gross Claims(GC) 2008-15

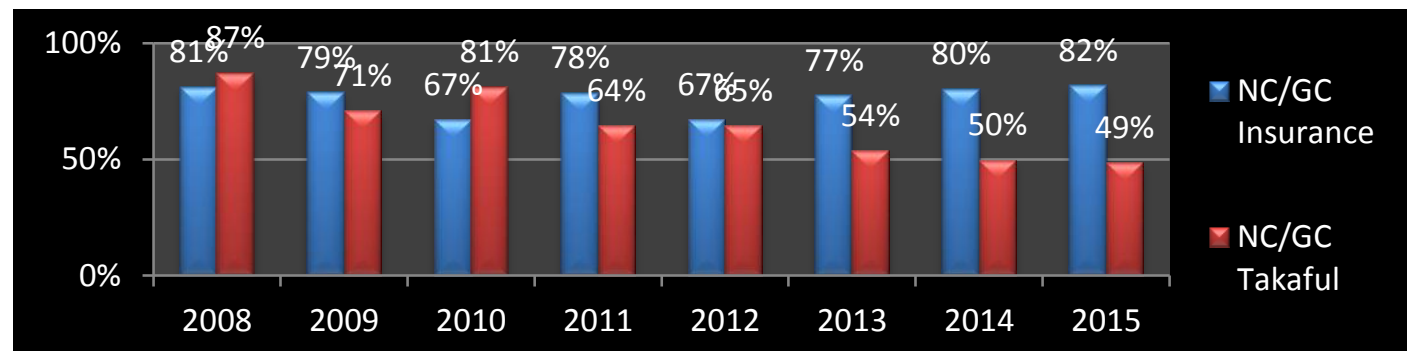

Data source: SBP-2015

Figure 9. Comparative returns on investments, in percent, of insurance funds 2008-15

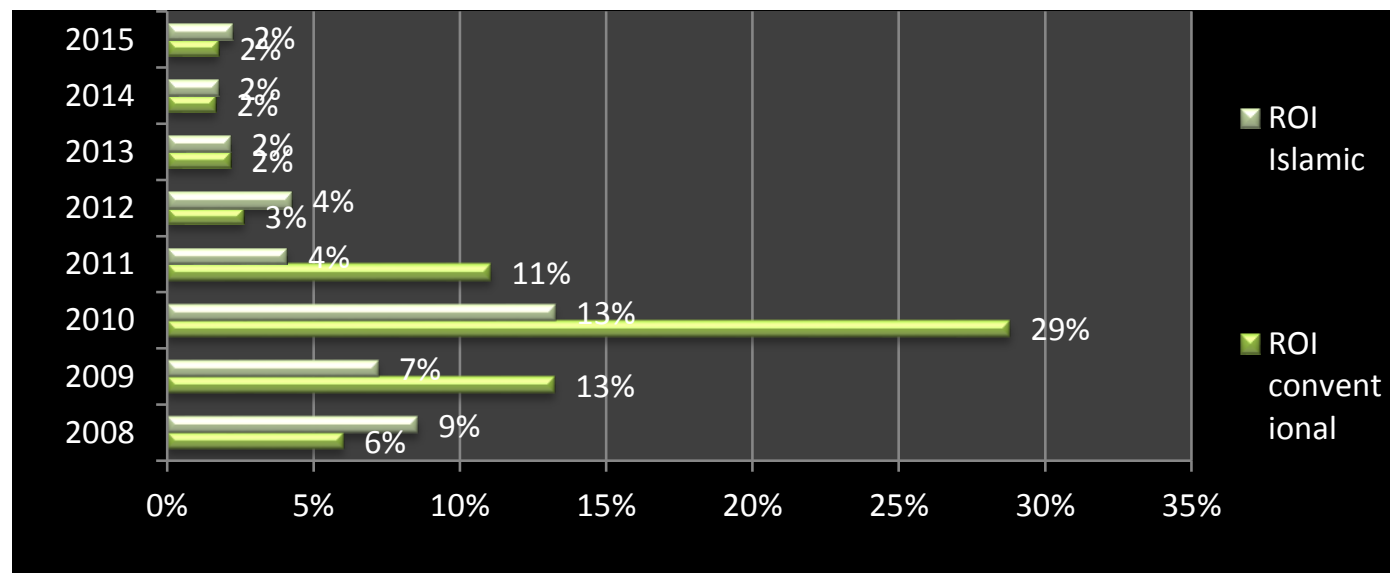

Data source: SBP-2015 


\section{2-Survey Results}

1. In Your opinion, Conventional Insurance Business is Halal [permitted] or Haram [prohibited], as per teachings of Islam?

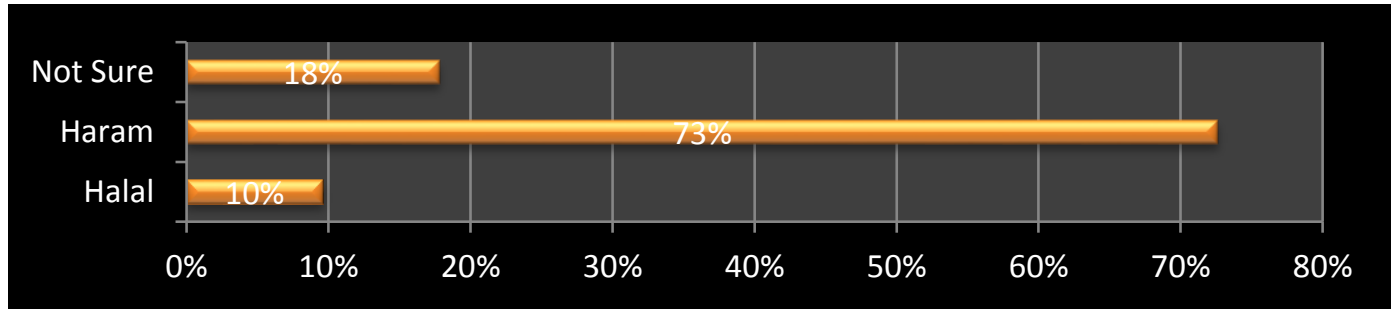

2. As per your understanding, what is/are underlying reason(s), which make(s) conventional insurance business Haram [prohibited], as per teachings of Islamic law? [Multiple options can be selected]

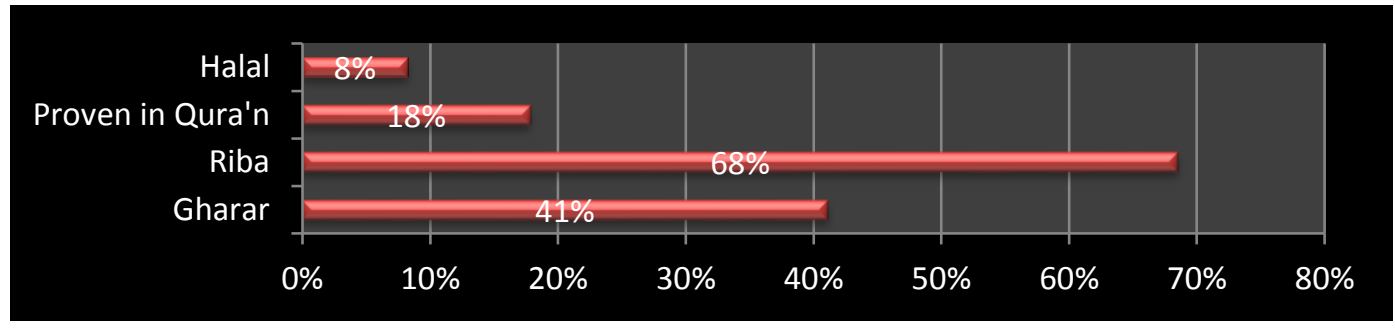

3. Have you ever been insured by yourself/employer/family/government/association? [Multiple options can be selected]

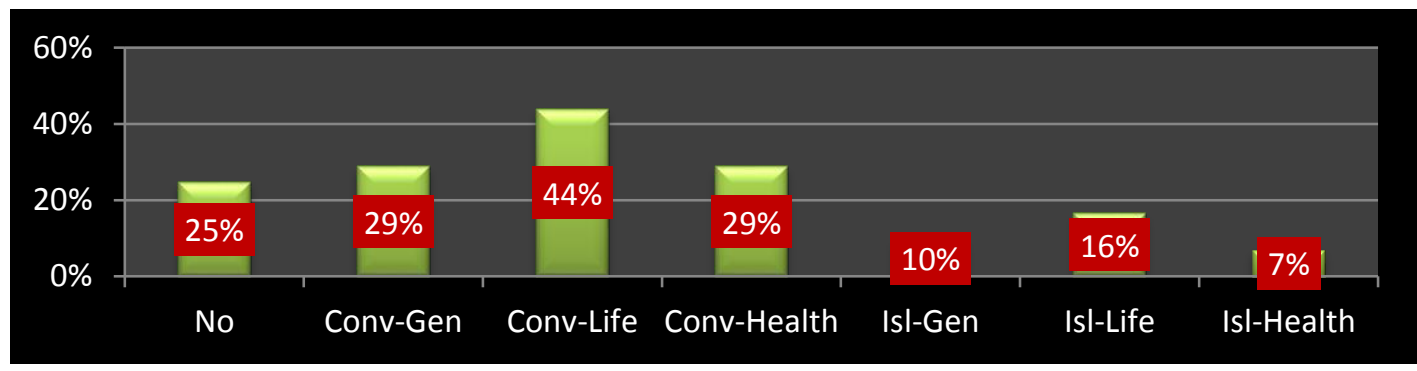


4. What is the underlying difference in the business models of a conventional and a Takaful company?[Multiple options can be selected]

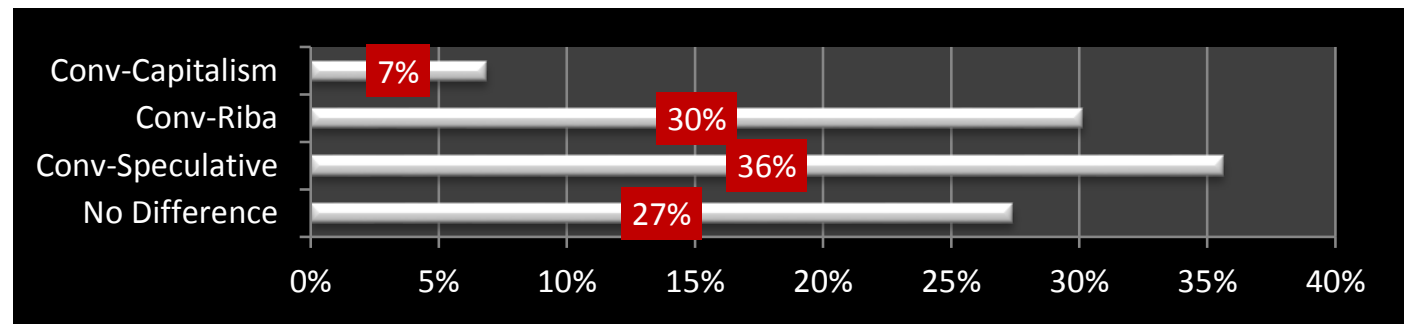

5. If new insurance product [Shari'a compliant] was available today at competitive rates, how likely would you be to use it instead of competing products [conventional insurance] currently available from other companies?

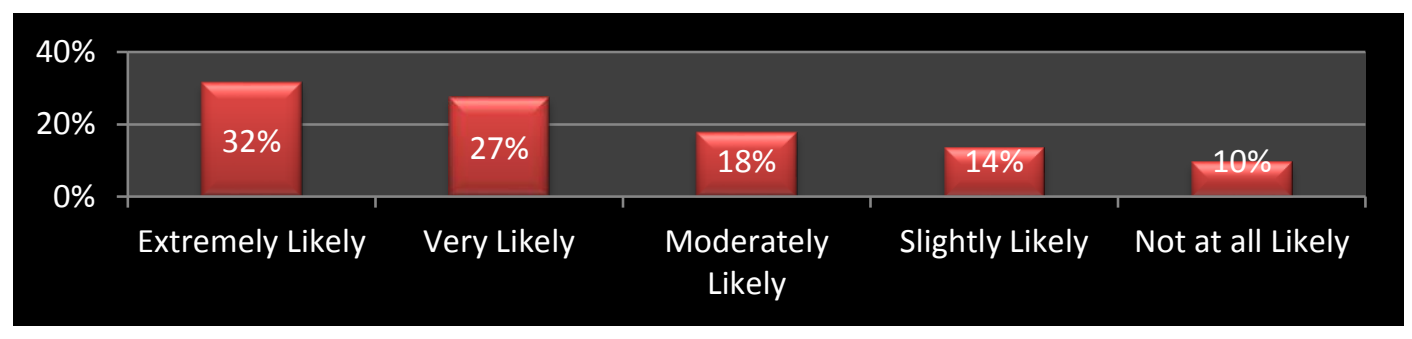

7. What is regulatory/Shari'a Supervisory/Audit state of Takaful business [companies] in

Pakistan? [Multiple options can be selected]

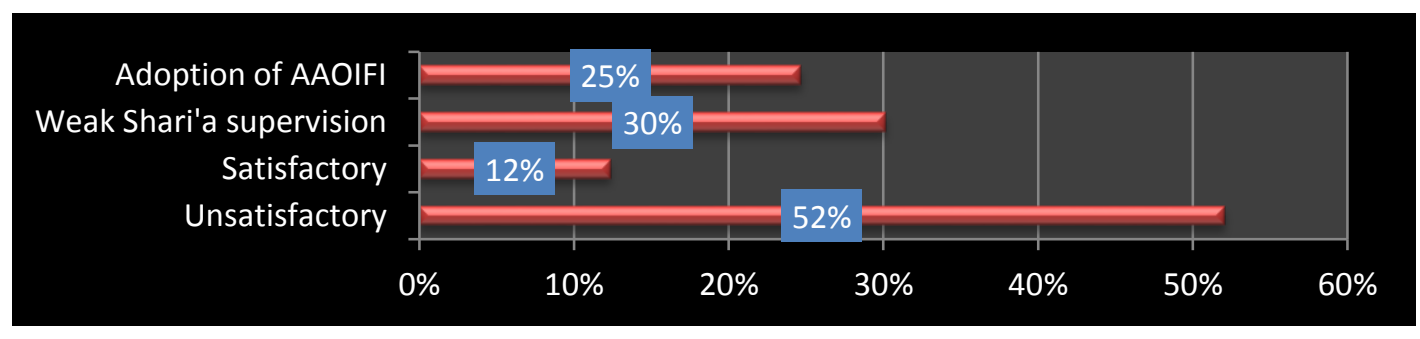


8. In your opinion, whether Shari'a compliant insurance business can meet total insurance needs of modern household/business customers?

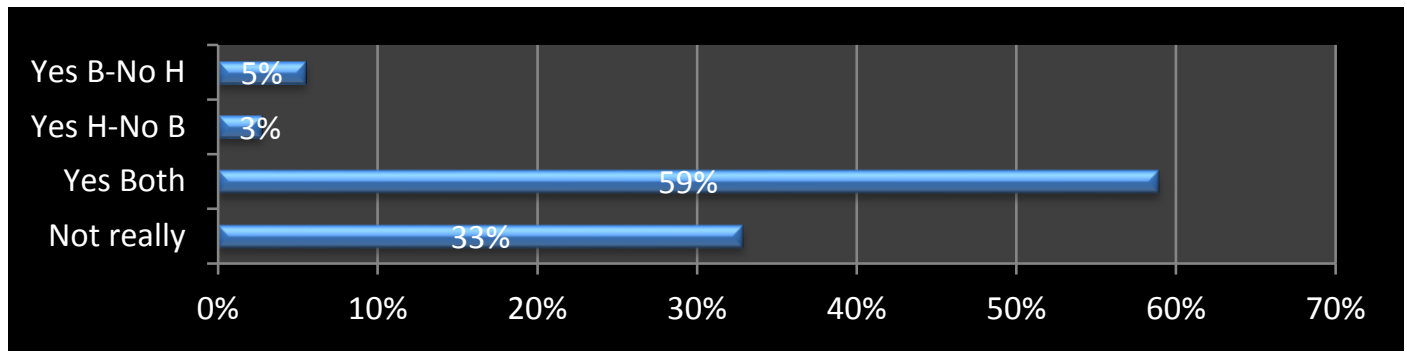

9. How do you see the future of Takaful business in Pakistan? [Multiple options can be selected]

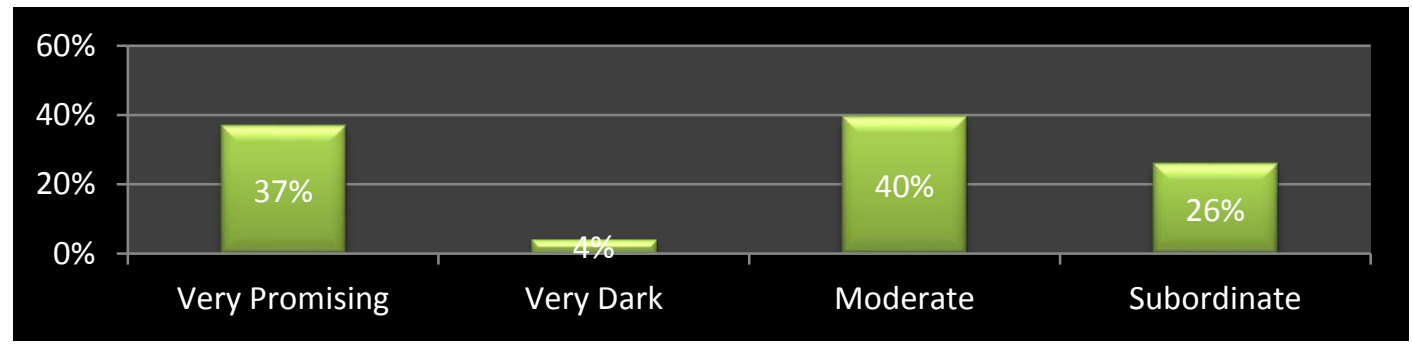

10. Islamic Finance is an emerging area with a very healthy growth and expansion globally but lacking trained Human resources, hence universities in Pakistan should provide Islamic finance education [Multiple options can be selected].

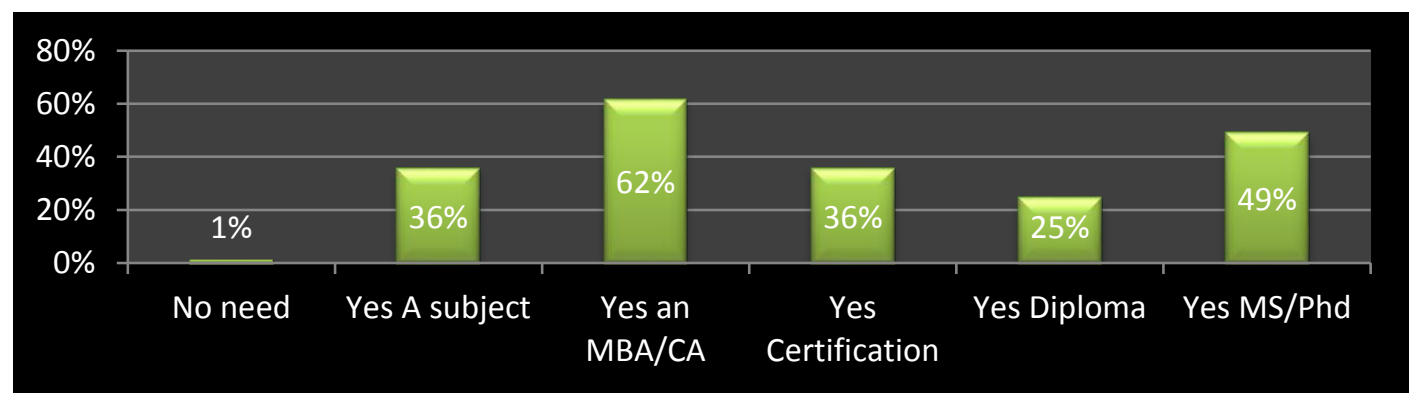

\footnotetext{
' http://jamaat.org/ur/jamaatOrDawat.php?cat id=11 accessed on September 24, 2014
} 
i"http://www.isdb.org/iri/portal/anonymous?NavigationTarget=navurl://24de0d5f10da906da85e 96ac356b7af0 accessed on September 24, 2014.

iii http://www.tabunghaji.gov.my/en/web/guest/profil-korporat accessed on September 24, 2014.

iv http://www.meezanbank.com/history.aspx accessed on September 24, 2014.

${ }^{v}$ http://iri.iiu.edu.pk/index.php/iri/content/id/71/ accessed on September 24, 2014.

vi http://www.ips.org.pk/publication/books accessed on September 24, 2014.

vii http://www.federalshariatcourt.gov.pk/8.html accessed on September 24, 2014.

viii http://www.albalagh.net/Islamic economics/riba judgement.shtml accessed on September 24, 2014.

${ }^{i x}$ http://www.aaoifi.com/en/about-aaoifi/our-history.html accessed on September 24, 2014.

x http://www.fighacademy.org.sa/ accessed on September 24, 2014.

\section{3-Summary of Shari'a Rulings on Insurance}

In this section, a summary of Shari'a rules taken from Shari'a Standard 26, issued by AAOIFI, is presented.

1. The managing company is entitled to its own capital and returns on capital, the agency fee, and its specific share of the actual profits earned by investing the insurance assets through Mudaraba or investment agency. The company also bears all the expenses of its operations including those relating to its task for investing the insurance assets.

2. The insurance fund is entitled to the contributions and the returns thereon, the provisions and reserves relating to insurance business, and the insurance surplus. The fund bears all direct expenses pertaining to management of insurance operations.

3. The relationship among participants is Musharaka; between participants and company is Wakala; and Mudaraba or investment agency; and relationship 
between insurance fund and participants is donation commitment (at the stage of making contributions) and of indemnification commitment (at the stage of compensation).

4. Donation commitment; and compensation commitment; and participants may undertake to bear any deficit that may occur, as per regulations.

5. Insurance company should maintain two accounts separately; one for its own rights and liabilities and other for the rights and liabilities of policyholders.

6. The role of the company is of an agent in managing the insurance account; is of Mudarib [Mudaraba Model] or an agent [Wakala Model] in investing the insurance assets.

7. The Insurance account is entitled to the insurance assets, returns on investments, and bears liabilities relating to these assets.

8. The adopted rules may comprise disposal of the surplus in a way that serves the cause of common interest of the participants (including accumulation of reserves, reduction of the contributions, charitable donations and distribution among participants). However the insurance company is not entitled to any share of the surplus.

9. In case of liquidation of an insurance company, all provisions and accumulated reserves pertaining to insurance should be spent for charitable purposes.

10. Preference should be given to policyholders to participate in the management of the insurance operations [e.g. representation in the board of directors].

11. Insurance company is required to adhere to the principles and rules of Islamic Shari'a in all its activities. 
12. A Shari'a supervisory board should be established; as well as an internal unit for Shari'a monitoring and auditing.

13. For a policyholder, the amount of contribution as well as benefit payable should be specified.

14. In case of death of a policyholder, Takaful entitlements should be distributed among the deserving persons, parties or purposes as indicated in the documents. However if deceased was entitled to some investment balances, then the same should be distributed among the inheritors according to the Islamic rules of inheritance.

15. In case of death benefit, it should be clearly stipulated that if the cause of death is 'murder' then the beneficiary cannot be a person involved in murder.

16. Non-Muslims can participate in various types of Takaful with Muslims.

17. The contribution may be determined according to the actuarial principles based on statistical techniques.

18. The risk that constitutes the subject matter of insurance should be one that could probably occur. It should not be something that relates to the absolute will of the participant, and should not encounter any Shari'a prohibition.

19. Submission of accurate information by policyholder about the risk insured is required. In addition, one should inform the company about any new circumstances that may contribute to increasing the risk. In case of fraud, deceit, and false information, one may be deprived from partial or full indemnity. In case of unintentional misrepresentation by policyholder, the indemnity shall become proportionate to the accurate information s/he presented. 
20. Payment of contribution on time, is required. In case of delay, company has the right to terminate the contract or pursue legal enforcement.

21. The participant shall receive equal to either the actual loss suffered or the insurance amount, whichever is less. The participants should not receive both the indemnity and the compensation from other parties for injury caused to him.

22. Insurance policy expires as under:

- Completion of agreed period

- Termination by company or participant, if it is stipulated

- Complete damage of insured property

- Death of the insured person. 